\begin{tabular}{|c|c|c|c|c|c|c|c|c|}
\hline \multicolumn{3}{|c|}{$\begin{array}{l}\text { 2. To: (Receiving Organization) } \\
\text { LMHC Remote Equipment } \\
\text { Engineering }\end{array}$} & \multicolumn{2}{|c|}{$\begin{array}{l}\text { 3. From: (originating Organization) } \\
\text { COGEMA Engineering Corp. }\end{array}$} & \multicolumn{4}{|c|}{$\begin{array}{l}\text { 4. Related EDT No.: } \\
\text { N/A }\end{array}$} \\
\hline \multicolumn{3}{|c|}{$\begin{array}{l}\text { 5. Proj./Prog./Dept./Div.: } \\
\text { DST Systems Integrity } \\
\text { Assessment Program }\end{array}$} & \multicolumn{2}{|c|}{$\begin{array}{l}\text { 6. Design Authority/ Design } \\
\text { Agent/Cog. Engr.: } \\
\text { N/A /TS Hunda]/RS Nicho] son } \\
\text { HJ2 } 20700 / N 4-3 e\end{array}$} & \multicolumn{4}{|c|}{$\begin{array}{l}\text { 7. Purchase Order No.: } \\
\qquad N / A\end{array}$} \\
\hline \multirow{2}{*}{\multicolumn{5}{|c|}{$\begin{array}{l}\text { 8. Originator Remarks: } \\
\text { This EDT transmits the data listed in block } 15 \text { for review } 1 / 6 / 98 \\
\text { and approval preparatory to release. }\end{array}$}} & \multicolumn{4}{|c|}{$\begin{array}{l}\text { 9. Equip./Component No.: } \\
\qquad N / A\end{array}$} \\
\hline & & & & & \multicolumn{4}{|c|}{$\begin{array}{l}\text { 10. System/Bidg./Facility: } \\
200 E / 200 \mathrm{~W}\end{array}$} \\
\hline \multirow{3}{*}{\multicolumn{5}{|c|}{ 11. Receiver Remarks: 11A. Design Baseline Document? [] Yes $[X]$ No }} & \multicolumn{4}{|c|}{$\begin{array}{l}\text { 12. Major Assm. Dwg. No.: } \\
\text { N/A }\end{array}$} \\
\hline & & & & & \multicolumn{4}{|c|}{$\begin{array}{l}\text { 13. Permit/Permit Application } \\
\text { No:: } \\
\text { N/A }\end{array}$} \\
\hline & & & & & \multicolumn{4}{|c|}{$\begin{array}{l}\text { 14. Required Response Date: } \\
\text { ASAP }\end{array}$} \\
\hline \multicolumn{2}{|l|}{15.} & \multicolumn{3}{|c|}{ DATA TRANSMITTED } & $(F)$ & (G) & $(\mathrm{H})$ & (I) \\
\hline $\begin{array}{l}\text { (A) } \\
\text { Iten } \\
\text { No. }\end{array}$ & (B) Document/Drawing No. & $\begin{array}{l}\text { (C) } \\
\text { Sheet } \\
\text { No. }\end{array}$ & $\begin{array}{l}(0) \\
\text { Rev. } \\
\text { No. }\end{array}$ & $\begin{array}{l}\text { (E) Title or Description of Data } \\
\text { Transmitted }\end{array}$ & $\begin{array}{l}\text { Approva? } \\
\text { Desig- } \\
\text { nator }\end{array}$ & $\begin{array}{l}\text { Reason } \\
\text { for } \\
\text { Trans- } \\
\text { mittal }\end{array}$ & $\begin{array}{l}\text { Origi- } \\
\text { nator } \\
\text { Oispo- } \\
\text { sition }\end{array}$ & $\begin{array}{l}\text { Receiv- } \\
\text { er } \\
\text { oispo- } \\
\text { sition }\end{array}$ \\
\hline 1 & HNF -3008 & N/A & 0 & $\begin{array}{l}\text { Double-Shel] Tank Waste } \\
\text { Transfer Facilities } \\
\text { Integrity Assessment Plan }\end{array}$ & $E$ & 1 & 1 & 1 \\
\hline
\end{tabular}

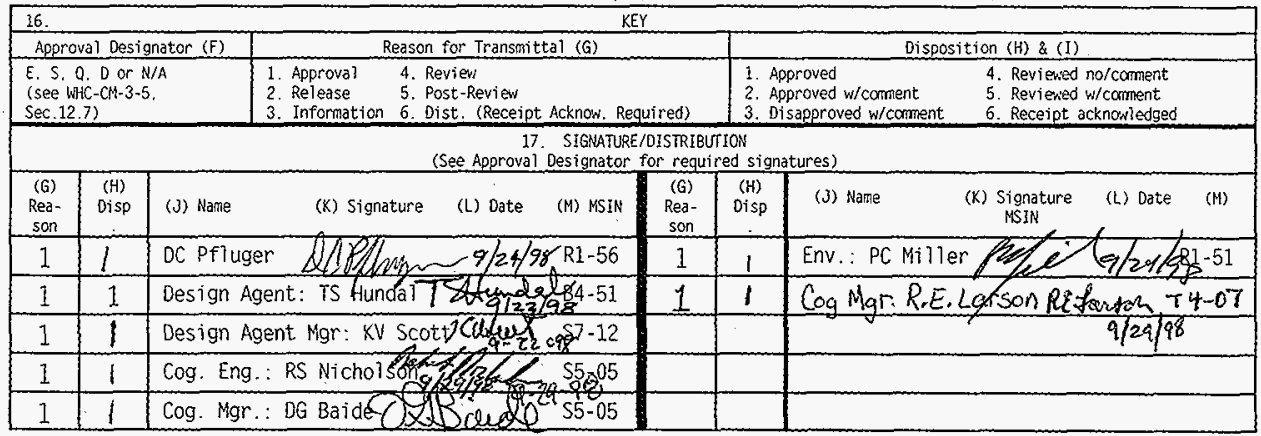

\begin{tabular}{|c|c|c|c|}
\hline $\begin{array}{l}18 . \\
\text { Is Hunda? } \\
\text { Signature of E⿱一𫝀) } \\
\text { Originator }\end{array}$ & 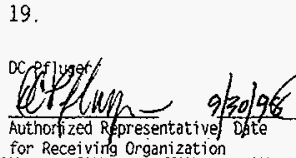 & 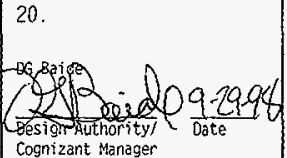 & $\begin{array}{l}\text { 21. DOE APPROVAL (if required) } \\
\text { Ctr1. No. } \\
\text { [] Approved } \\
\text { [] Approved w/Comments } \\
\text { [] Disapproved w/comments }\end{array}$ \\
\hline
\end{tabular}


HNF-3008, Rev. 0

\title{
Double-Shell Tank Waste Transfer Facilities Integrity Assessment Plan
}

\author{
T. S. Hundal \\ COGEMA Engineering Corporation, Richland, WA 99352 \\ U.S. Department of Energy Contract DE-AC06-96RL13200 \\ EDT: 618717 \\ UC: $630106696 /$ CA40 \\ kN $10 / 6 / 98$ \\ Org Code: $08 \mathrm{E} 00$ \\ B\&R Code: EW3120074 \\ Charge Code: 3 C/HJ220700 \\ Total Pages: 12
}

KEY WORDS: Double-shell tank, DCRT, catch tanks, A-350 lift station, 204-AR waste unloading facility, integrity assessment plan, design standards, waste characteristics and compatibility, corrosion protection, tank age, integrity examination, integrity assessment report.

REFERENCE DOCUMENT: WAC-173-303-640

ABSTRACT: This document presents the integrity assessment plan for the existing double-shell tank waste transfer facilities system in the 200 East and 200 West Areas of Hanford Site. This plan identifies and proposes the integrity assessment elements and techniques to be performed for each facility. The integrity assessments of existing tank systems that stores or treats dangerous waste is required to be performed to be in compliance with the Washington State Department of Ecology Dangerous Waste Regulations, Washington Administrative Code WAC-173-303-640 requirements.

TRADEMARK DISCLAIMER. Reference herein to any specific commercial product, process, or service by trade name, trademark, manufacturer, or otherwise, does not necessarily constitute or imply its endorsement, recommendation, or favoring by the United States Government or any agency fhereof or its contractors or subcontractors.

Printed in the United States of America. To obtain copies of this document, contact: Document Control Services, P.O. Box 950, Mailstop H6-08, Richland WA 99352, Phone (509) 372-2420; Fax (509) 376-4989.

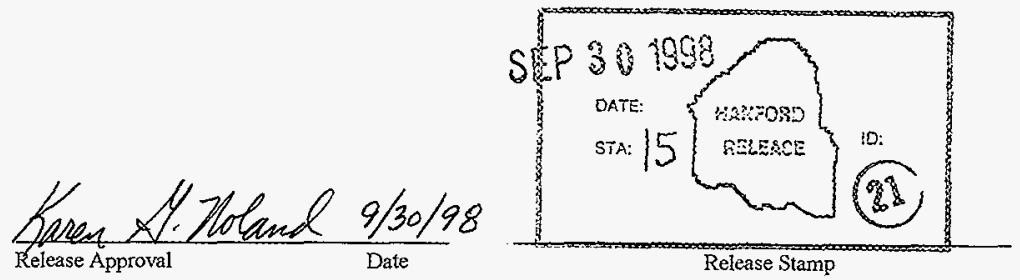

\section{Approved for Public Release}


HNF-3008

Rev. 0

\section{DOUBLE-SHELL TANK WASTE TRANSFER FACILITIES INTEGRITY ASSESSMENT PLAN}

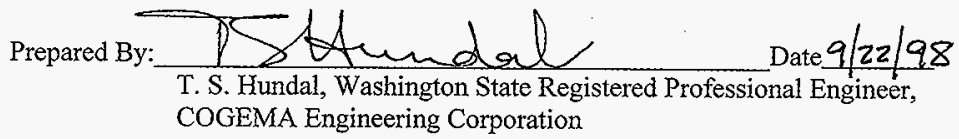

Reviewed By: $\frac{\varkappa \text { Lleoff }}{\text { K. V. Scott, COGEMA Engineering Corporation }}$ Date $9 / 22 / 98$

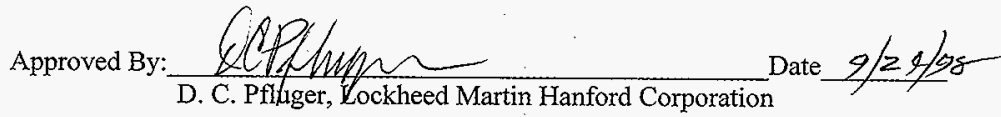


FINF-3008

Rev. 0

\section{DOUBLE-SHELL TANK WASTE TRANSFER FACHLITIES INTEGRITY ASSESSMENT PLAN}

\section{CONTENTS}

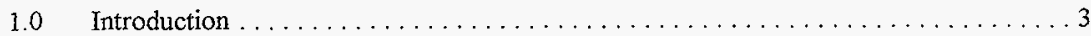

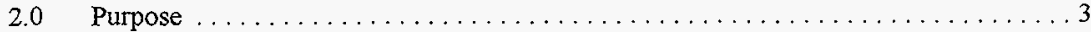

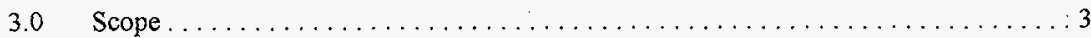

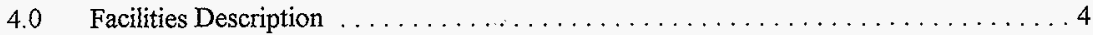

4.1 Double-Contained Receiver Tanks (DCRTs) $\ldots \ldots \ldots \ldots \ldots \ldots \ldots \ldots$

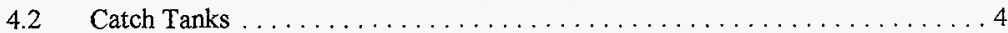

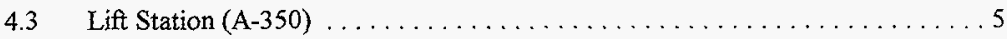

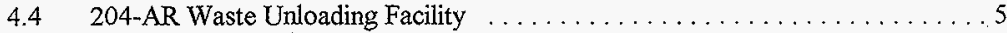

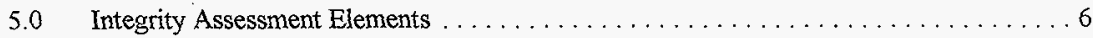

$5.1 \quad$ Design Standards . . . . . . . . . . . . . . . . . . . . . . 6

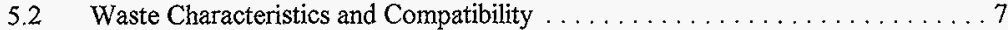

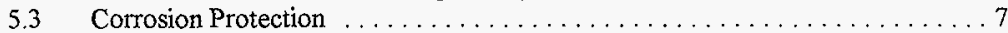

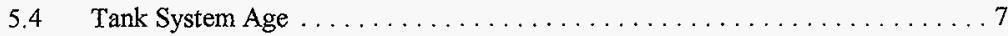

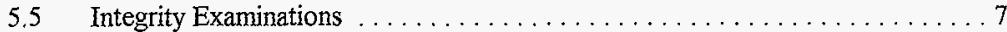

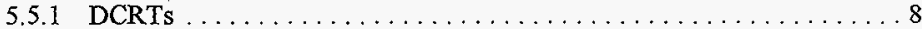

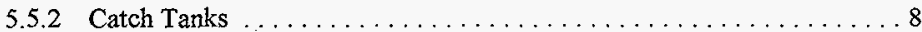

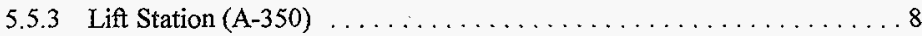

$5.5 .4 \quad$ 204-AR Waste Unloading Facility $\ldots \ldots \ldots \ldots \ldots \ldots \ldots \ldots$

6.0 Subsequent Integrity Assessments $\ldots \ldots \ldots \ldots \ldots \ldots \ldots \ldots \ldots \ldots \ldots$

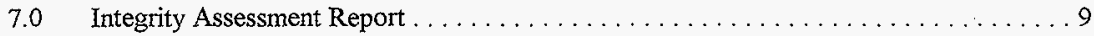

8.0 Certification of Integrity Assessments . . . . . . . . . . . . . . . . . . . 9

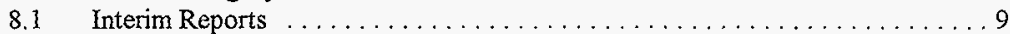

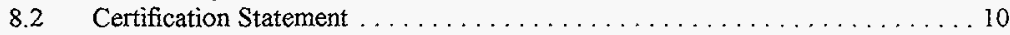

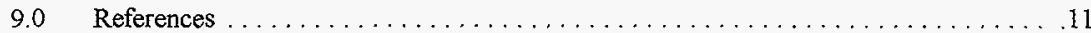


HNF-3008

Rev. 0

\subsection{Introduction}

The Lockheed Martin Hanford Corporation operates a network of interconnecting underground piping and ancillary equipment within the double-shell tank (DST) and single-shell tank (SST) systems for the U. S. Department of Energy-Richland Operations (DOE-RL). These tank systems are in the 200 East and 200 West Areas of the Hanford Site located north of Richland in the southeast portion of Washington State. Some of these tank systems have been in service for over 50 years and contain dangerous waste constituents as defined by Washington State Department of Ecology (WDOE) Dangerous Waste Regulations, Washington Administrative Code (WAC) 173303-040. Chapter 173-303-640(2) of the WAC requires the performance of integrity assessments for each existing tank system that stores or treats dangerous wastes. This requirement states that for each existing tank system, the owner or operator must determine that the tank system is not leaking or is unfit for use. It further states that the owner and/or operator must obtain and keep on file at the facility, a written assessment reviewed and certified by an independent qualified registered professional engineer (IQRPE).

\subsection{Purpose}

This integrity assessment plan (IAP) identifies all facilities to be evaluated and describes the proposed integrity assessment elements and techniques to be performed for each facility. The integrity assessment (IA) is to determine the present condition of an existing facility and that its components are leak tight and structurally stable for the duration of its intended use. The IA will also determine if the codes, standards, and regulations used to design, construct, and maintain the facility are adequate to protect the environment and the public health. From the results of this IA evaluation, appropriate conclusions and recommendations will be documented for each facility.

The evaluation (design analysis and examination) described in this IAP will provide the necessary information to enable the IQRPE, T. S. Hundal or an alternate from COGEMA Engineering Corporation, to certify the assessment reports.

\subsection{Scope}

This plan covers four DCRTs, eight Catch Tanks, one Lift Station, and one Waste Unloading Facility. The DSTs, miscellaneous pits such as diversion boxes, pump pits, valve pits, piping, and previously completed assessments are not included in this plan. They are addressed in separate documents (Hundal 1997, McClusky 1997, Sutherland 1991, Walter 1995). 
HNF-3008

Rev. 0

\subsection{Facilities Description}

\subsection{Double-Contained Receiver Tanks (DCRTs)}

Listed below are four DCRT systems in the 200 Area: two each in the 200 East and 200 West Areas. The DCRT system functions as a small capacity (nominal 16,000 to 31,000 gallons), short-term waste holdup station during waste transfers. At the Hanford Site, the terms "lift station" and "DCRT" have been used synonymously with "catch station." Each station consists of an underground concrete structure that houses a steel receiver tank (primary containment) in a vault (secondary containment), a pump pit (secondary containment), the ancillary waste-transfer equipment, and other pits that do not process or store liquid waste. The steel receiver tank contains liquid waste most of the time. The air space between the steel tank and the concrete vault is called the annulus.

244-A Lift Station (vertical receiver tank)

244-S Catch Station 244-BX Saltwell Station 244-TX Catch Station (vertical receiver tank) (horizontal receiver tank) (horizontal receiver tank)

All DCRTs include the following:

$\begin{array}{ll}\text { - } & \text { Annulus } \\ \text { - } & \text { Alarm and Annunciators } \\ & \text { System Liquid Level Instrument } \\ \text { - } & \text { Ventilation System } \\ \text { - } \quad \text { Leak Detection System } \\ \quad \quad \text { Separate Instrument Building }\end{array}$

\subsection{Catch Tanks}

There are eight small underground tanks associated with the Hanford Site Tank Farms, which are used to provide interim secondary containment for any waste spillage, transfer line flush water, rainwater or snowmelt water draining into them. They are primarily used to provide secondary containment for transfer lines, seal loops, valve and pump pits, and/or diversion boxes. They are constructed of different material ranging from carbon steel to concrete. Access to these tanks is either through the pump pits or the risers above them. These tanks are equipped with a leak detection device such as a surface mounted liquid level indicator/sensor (manual tape, or FIC level gauge) etc. 
HNF-3008

Rev. 0

Table-1 Catch Tanks

\begin{tabular}{|c|c|c|c|}
\hline \multicolumn{2}{|c|}{200 East Area } & \multicolumn{2}{|c|}{200 West Area } \\
\hline Catch Tank & Approx. Size/Material & Catch Tank & Approx. Size/Material \\
\hline 241-ER-311 & $\begin{array}{l}9 \mathrm{ft} \text { OD } \times 36 \mathrm{ft} L \\
1 / 2^{\prime \prime} \text { SST plate }\end{array}$ & $241-S-304$ & $\begin{array}{l}9 \mathrm{ft} \mathrm{OD} \times 15 \mathrm{ft} \mathrm{H} \\
5 / 8^{\prime \prime} \mathrm{SA} 516-70 \text { plate }\end{array}$ \\
\hline $241-A X-152$ & $\begin{array}{l}22 \mathrm{ft} \mathrm{L} \times 6 \mathrm{ft} \mathrm{W} \times 12 \mathrm{ft} \mathrm{D} \\
\text { Concrete lined with } 1 / 8^{\prime \prime} \\
\text { SST plate }\end{array}$ & $241-\mathrm{TX}-302 \mathrm{C}$ & $\begin{array}{l}9 \mathrm{ft} \text { OD } \times 39 \mathrm{ft} \text { Long } \\
9 / 16^{\prime \prime} \text { carbon steel plate }\end{array}$ \\
\hline 241-AZ-151 & $\begin{array}{l}26 \mathrm{ft} \mathrm{L} \times 8 \mathrm{ft} \mathrm{W} \times 12 \mathrm{ft} \mathrm{D} \\
\text { concrete, below a } 16 \mathrm{ft} \\
\text { deep pump pit, lined with } \\
10 \text { gage } \mathrm{A}-569 \text { plate }\end{array}$ & 241-U-301B & $\begin{array}{l}\text { Prestressed Concrete } \\
\text { Tank } 21 \mathrm{ft} \text { OD } \times 21 \mathrm{ft} \\
5^{\prime \prime} \text { thick wall. Interior } \\
\text { coated with } 3 / 4 " \text { thick } \\
\text { layer of Gunite }\end{array}$ \\
\hline $\begin{array}{l}241-E W-151 \\
\text { Air Vent Station } \\
\text { Between East \& } \\
\text { West Areas }\end{array}$ & $\begin{array}{l}4 \mathrm{ft}-7 \text { in. dia.x } 6 \mathrm{ft}-10 \text { in. } \mathrm{H} \\
5 / 16^{\prime \prime} \text { SST plate }\end{array}$ & 241-UX-302A & $\begin{array}{l}9 \mathrm{ft} \mathrm{ID} \times 39 \mathrm{ft} \mathrm{L} \\
9 / 16^{\prime \prime} \mathrm{A}-285 \mathrm{Gr} \cdot \mathrm{B} \text { plate }\end{array}$ \\
\hline
\end{tabular}

\subsection{Lift Station (A-350)}

The lift station is located southeast of Tank 241-A-106 in Tank Farm A in the 200E Area. It is constructed of reinforced concrete and has an $11 \mathrm{ft} \times 11 \mathrm{ft} \times 12 \mathrm{ft}$ pump pit over an 8 -ft-dia. $\times 17$ $\mathrm{ft}$-high caisson that houses the vertical stainless steel, 750-gallon, 4-1/2-ft-dia. $\times 7 \mathrm{ft}-8 \mathrm{in}$. high 241-A-350 catch tank. The catch tank receives condensate/drainage waste from various sources including 242-A Evaporator, valve pits, and clean out boxes (COBs), and is part of the secondary containment system. The pump pit floor slopes to a 3 inch diameter seal loop drain directing any leaks into the catch tank below. The caisson is accessible through an entryway in the pump pit floor and there is a 21 -in. annulus space between the tank and the caisson. The caisson also has a sump with a leak detection probe and a sump pump.

\subsection{4-AR Waste Unloading Facility}

The 204-AR Facility receives liquid waste transported in railroad tank cars or tank trailers for direct transfer to DSTs via the 241-AA valve pit. The facility is located in the 200 East Area and is housed in a two-story, structural steel, reinforced concrete building. The facility has five tanks. Four above ground tanks (most of the time empty) are filled with desirable amount of various chemical solutions at the time of waste transfer from rail tank car or tank trailer to a DST. 
HNF-3008

The chemical solutions from these tanks are used for treating the waste prior to its transfer to the DST so that it is compatible with the DST waste composition specifications. The fifth tank is the underground stainless steel catch tank for liquid waste collection. Any spills in the facility or decontamination solutions drain to the floor and are collected in a stainless steel drain system for collection into this 1,500-gal catch tank which is surrounded by a steel lined concrete vault. Waste removal equipment is provided for the tank and the vault.

The vault annulus space surrounding the catch tank is accessible through a steel grate-covered opening in the floor above the catch tank. There is a leak detector in the catch tank vault sump and a high liquid level detector in the catch tank. These two detectors interlock with motoroperated valves (MOVs) in the waste solution transfer line from the tank car. In case of high liquid level in the catch tank or overflow to the sump, these MOVs are activated (closed) thus blocking all waste flows to the catch tank.

\subsection{Integrity Assessment Elements}

The WAC 173-303-640 (2) (c) regulations require that integrity assessments of existing tank systems be conducted to "determine that the tank system is adequately designed and has sufficient strength and compatibility with the waste(s) to be stored or treated, to ensure that it will not collapse, rupture, or fail." As a minimum, this assessment must consider the following:

(i) Design Standards to which the tank system was designed and constructed.

(ii) Characteristics of the waste(s) and its (their) compatibility to the tank components.

(iii) Existing corrosion protection.

(iv) Age of the tank system.

(v) Examinations (leak test, internal inspection, or other tank system integrity examination).

\subsection{Design Standards}

The integrity assessment report will identify the design standards, codes, or regulations used to design, construct, maintain, and operate the facility. The report will identify and demonstrate its compliance to the requirements of their latest revisions as applicable. The report will include the review of the design or alternate calculations with special attention to the adequacy of foundation and wall strength to sustain applicable design loads. The report will also identify any new regulatory requirements and evaluate their impact, and identify any action required to have the facility compliant with the new regulations. 
HNF-3008

Rev. 0

\subsection{Waste Characteristics and Compatibility}

Duting the last 50 years, various Hanford facilities used several chemical processes to separate weapon grade material from nuclear products. The operation of these facilities generated waste that was transferred through the DST waste transfer system. The range of chemical compounds and waste concentrations varies widely, depending on the type of waste, the source, and the degree to which it has been concentrated. These wastes will be reviewed for constituents and characteristics that may damage the facility components.

Each facility and its components will be evaluated for their compatibility to store, handle, transfer, and/or process various waste solutions handled by it. Historical data documents may be used to identify various waste materials the facility has handled. A comparison will be made of the waste types with material compatibility tables published by the National Association of Corrosion Engineers and the American Society of Metals. Tank waste chemicals, and other monitored characteristics will be discussed to demonstrate the care and caution used to maintain the tank.

\subsection{Corrosion Protection}

Any internal or external corrosion protection measures incorporated in the design, construction, and operation phases will be identified. And also, the effectiveness of the in-place corrosion protection will be evaluated. If any additional protection or improved mitigating corrosion protection methods are prudent, these will be recommended to enhance the protection against corrosion.

\subsection{Tank System Áge}

The facility age will be identified along with its expected service life.

\subsection{Integrity Examinations}

In order to further substantiate the structural integrity of each facility, it will be examined for any leaks, defects, and/or cracks. The examination may be a leak test, visual examination with or without the closed circuit television (CCTV) camera, or any combination thereof. Acceptance criteria will be established for each leak test. Historical liquid level monitoring data and data from leak detection instruments may also be documented and used as a proof of leak test. The visual examinations will determine if there is evidence of damage, leaks, or severe corrosion. Any defects or findings will be recorded and identified with appropriate recommendations as required. 


\subsubsection{DCRTs}

Tank and vault examinations, leak tests, and visual examination will be performed as described in the integrity assessment plan (Sutherland 1991). Since each facility has similar components, their examinations will also be similar. The receiver tank will be accessed through the pump pit floor. Therefore, the pump pit cover blocks will have to be removed, for the inside of the tank to be examined by lowering a remote controlled CCTV camera through one of the spare risers. Prior to the tank examination, the pump pit will also be visually inspected with this camera. The vault annulus space surrounding the tank can either be accessed and inspected from an inspection riser at ground level or in some cases through the pump pit floor risers. In either case the remote controlled CCTV camera will be lowered through these risers for the tank leak test or for visual examination of the outside surface of tank and inside surface of the vault.

\subsubsection{Catch Tanks}

A leak test will be performed on each tank using normal waste fluids at the maximum tank liquid level allowed by Hanford safety and operational regulations. Visual examinations of the inside of tank will be performed by lowering the CCTV camera through the available risers. This visual examination will be performed when the tank is empty as much as possible.

\subsubsection{Lift Station (A-350)}

A leak test on the drain tank will be performed and visual inspection with remote CCTV camera will be performed on the inside of the drain tank and the vault annulus area.

\subsubsection{4-AR Waste Unloading Facility}

A leak test will be performed on the underground tank only. The internal surface of the underground tank will be inspected with a CCTV camera by inserting it through a spare riser and its outside surface and pit floor will be visually examined directly through the grating at ground level.

\subsection{Subsequent Integrity Assessments}

At the conclusion of the integrity assessment activities, and after all data have been evaluated, a schedule for subsequent integrity assessments will be recommended. The recommended schedule will be based on the results of this assessment and past integrity assessments, age of the tank system, materials of construction, characteristics of the waste, and any other relevant factors such as the facility condition and its future service demands. 


\subsection{Integrity Assessment Report}

A written report providing the results of the facility integrity assessment conducted as per Section 5.0 shall be prepared by a qualified person. This report shall be reviewed and certified by the IQRPE, T. S. Hundal or an alternate from COGEMA Engineering Corporation, and given to the facility owner/operator. The assessment report shall contain the following items:

- Site map of the facility showing the location of the tank system within the overall facility.

- A sketch of the tank system and location of the inspected item clearly indicating and cross-referencing the results of the integrity assessment.

- Results of the structural integrity assessment including the leak testing or other methods used to assess tank system integrity. The results should clearly state whether the tank system has sufficient structural strength and compatibility with the waste being stored or handled to remain in service.

- Results of the secondary containment assessment.

- Results of the tank system corrosion assessment.

- A recommended schedule for future tank system integrity assessments to ensure that the tank retains its structural integrity and will not collapse, rupture, or fail.

- A statement by the IQRPE certifying the results of the integrity assessment.

- Conclusion and recommendations.

\subsection{Certification of Integrity Assessments}

\subsection{Interim Reports}

During interim stages of their preparation, the integrity assessment reports and supporting information/documentation will be provided to the IQRPE for review and comments. 
HNF-3008

Rev. 0

\subsection{Certification Statement}

The IQRPE will sign and place his/her stamp certifying the integrity assessment report as follows:

"I certify under penalty of law that I have personally examined and am familiar with the information submitted in this document and all attachments and that, based on my assessment of the plans and procedures utilized for obtaining this information, I believe that the information is true, accurate, and complete. I am aware that there are significant penalties for submitting false information, including the possibility of fine and imprisonment." 
HNF-3008

Rev. 0

\subsection{References}

Hundal, T. S., 1997, Double-Shell Tank waste Transfer Piping/Pit System Integrity Assessment Plan, HNF-SD-WM-ER-623, SGN Eurisys Services Corporation, Richland, Washington, November 1997.

Karwoski, W. J., 1991, Engineering Study-Catch Tanks Environmental Upgrades for Tank Farms, WHC-SD-WM-ES-156, Westinghouse Fanford Company, Richland, Washington, March 1991.

Mattichak, R. W., 1997, Catch Tanks Code Compliance Evaluation and Alternatives Study, HNFSD-TWR-ES-005, Numatec Hanford Corporation, Richland, Washington, March 1997.

Pfluger, D. C., 1994, Tank System Integrity Assessment Plan, WHC-SD-WM-AP-017, Westinghouse Hanford Company, Richland, Washington, June 1994.

WAC 173, Washington State Department Of Ecology, State of Washington Administrative Code, Dangerous Waste Regulations, WAC 173-303-640, Olympia, Washington.

Sutherland, D. G., 1991, Integrity Assessment Plan for the Double-Contained Receiver Tanks and Designated Ancillary Equipment, WHC-SD-WM-WP-068, Westinghouse Hanford Company, Richland, Washington, March 1991.

Walter, E. J., 1995, 244 U Double-Contained Receiver Tank Facility Integrity Assessment Report, WHC-SD-WM-RPT-092, Westinghouse Hanford Company, Richland, Washington. August, 1995.

McClusky, J. K., 1997, Letter from J. K. McClusky (DOE-RL) to H. J. Hatch (FDH), (Letter No. 97-WSD-258, Dated December 23, 1997), Contract Number DE-AC06-96RL13200-U.S. Department of Energy, Richland Operations Office (RL), Double-Shell Tank (DST) System Integrity Program Plan. 


\section{DISTRIBUTION SHEET}

\begin{tabular}{|c|c|c|c|c|c|}
\hline \multirow{2}{*}{$\begin{array}{l}\text { To } \\
\text { Distribution }\end{array}$} & \multirow{2}{*}{\multicolumn{3}{|c|}{$\begin{array}{l}\text { From } \\
\text { Remote Equipment Engineering }\end{array}$}} & \multicolumn{2}{|c|}{ Page 1 of 1} \\
\hline & & & & \multicolumn{2}{|c|}{ Date $\quad 9 / 30 / 98$} \\
\hline \multirow{2}{*}{\multicolumn{4}{|c|}{$\begin{array}{l}\text { Project Title/Work Order } \\
\text { Double-She } 17 \text { Tank Waste Transfer Facilities } \\
\text { Integrity Assessment Plan (HNF-3008). }\end{array}$}} & \multicolumn{2}{|c|}{ EDT No. 618717} \\
\hline & & & & \multicolumn{2}{|c|}{ ECN No. } \\
\hline Name & MSIN & $\begin{array}{l}\text { Text } \\
\text { with } \\
\text { All } \\
\text { Attach. }\end{array}$ & $\begin{array}{l}\text { Text } \\
\text { Only }\end{array}$ & $\begin{array}{l}\text { Attach./ } \\
\text { Appendix } \\
\text { Only }\end{array}$ & $\begin{array}{l}\text { EDT/ECN } \\
\text { Only }\end{array}$ \\
\hline
\end{tabular}

Central files

B1-07

$x$

D. I. Allen

R2-50

D. G. Baide

$\$ 5-05$

D. A. Bragg

S5-05

C. B. Bryan

$\$ 5-07$

W. E, Bryan

S5-05

L. F. Dougherty

T4-08

B. G. Erlandson

R1-51

M. O. Harding

R4-04

W. M. Harty

S5-13

T. S. Hunda 1

B4-51

K. J. HuT1

T4-07

P. F. Kison

T4-07

T. J. Kelley

S5-07

R. E. Larson

T4-07

P. C. Miller

R. S. Nicholson

R1-51

S5-05

L. T. Pedersen

RI-56

D. C. Pfluger

M. L. Ramsay

R1-56

S7-54

D. W. Reberger

S5-13

R. W. Reed

T4-07

D. S. Rewinkel

S7-40

C. 3. Rice

R2-50

S. H. Rifaey

R1-56

E. B. Schwenk

L6-38

K. V. Scott

S7 -12

D. B. Smet

RI-56

M. J. Sutey

T4-08

J. J. Zimmer

B4-51

$x$

$x$

$x$

$x$

$x$

$x$

$x$ 